\title{
Elektron dövlət mühitində uşaqların İnternet təhlükəsizliyinin qanunvericilik bazasının formalaşdırılması problemləri
}

\author{
Sabirə Ocaqverdiyeva \\ AMEA İnformasiya Texnologiyaları İnstitutu, Bakı, Azərbaycan \\ allahverdiyevasabira@gmail.com
}

\begin{abstract}
Xülaso - Məqalədə uşaqların İnternet mühitində qaşılaşdığı təhlükələr analiz olunaraq təsnifatlandırılır. Uşaqların İnternet mühitində təhlükəsizliyinin təmin olunması ilə əlaqədar dünyanın müxtəlif ölkələrində və Azərbaycanda dövlət səviyyəsində, qanunvericilik əsasında qəbul edilmiş normativ sənədlər haqqunda məlumat verilir.
\end{abstract}

Açar sözlor - uşaqların tohlükosizliyi, ziyanlı kontent, zororli informasiya, internet tohlükolori, asılılıq.

\section{GİRIŞ}

İnternetin sürətlə inkişafi və bütün sahələrə tətbiqi istifadəçilərə geniş imkanlar yaradır. İnternet istifadəçilərinin sayı getdikcə artmaqda davam edir və informasiya mübadiləsi çoxalır. Virtual məkanda, əsasən də sosial mediada, son zamanlar geniş yayılan pornoqrafiya, işgəncə, qəddarlıq səhnələri, narkotik, spirtli içkilərin, terrorizm, vandalizm, pis vərdişlərin və $\mathrm{s}$. təbliğatını aparan kontentlərin sayı artmaqdadır. Uşaqlar onlayn mühitdə istifadəçi kimi fəal olduqlarından, informasiya mübadiləsi zamanı onların qeyd olunan kontentlərlə qarşılaşma ehtimalı böyükdür.

Veb-səhifələrdə arzuolunmaz mənəvi və əxlaqi keyfiyyətləri aşılayan kontentlər yetərincə boldur. $\mathrm{Bu}$ kontentlər uşaqların yaşa uyğun olmayan şəkillərlə, cinsi istismarı, aqressiyanı və zorakılığı təbliğ edən mətnlərlə rastlaşmasına səbəb olur.

İnternetdən əldə olunan bir çox məlumatlar uşaq psixologiyasına təsir edir. Onlarda qorxu, təlaş, dəhşət, vahimə kimi hisslərinin yaranmasına və kibercinayətkarların hədəfinə çevrilməsinə səbəb olur. Uşaqların əksəriyyəti İnternetdə aldadılır, zorakılığa məruz qalır, texniki və sosialpsixoloji təhdidlərlə üzləşir [1].

Uşaqların hər hansı bir ziyanlı məlumatdan qorunması vacibdir. Son on-on beş il ərzində elmi ədəbiyyatda uşaqların təhlükələrlə qarşılaşma risklərinin tədqiqi ilə bağlı məlumatlar kifayət qədərdir. Bu məlumatlar əsasən kompüter təhlükələrinə və onların yaratdığı ziyanın nəticələrinə yönəlmişdir [2, 3].
Texnologiyaların inkişaf tempi elektron dövlət mühitində təhlükəsizliyin təmin edilməsi ilə bağlı yeni tələblər yaradır. İnformasiya təhlükəsizliyi məsələləri milli təhlükəsizliyin əsas tərkib hissələrindən biri olduğuna görə qeyd etmək olar ki, uşaqların İnternet mühitində qorunması məsələləri tamın bir hissəsi kimi yanaşma tələb edir.

\section{UŞAQLARIN İNTERNET MÜHITTINDӘ QARŞILAŞDIĞI TӘHLÜKӘLӘR}

Qeyd edək ki, "uşaq" dedikdə, 18 yaşına çatmamış şəxslər başa düşülür. Yəni bu termin yalnız azyaşlılara aid edilmir, uşaq və yeniyetmələr də bu qrupa daxildir. Onlar daha çox sosial şəbəkələr, çatlar, oyun otaqları, onlayn alışveriş, forum və s. kimi virtual məkanlarda ziyanlı kontentlə üzləşirlər. İnternetdə işləyərkən onların həm özünün, həm də istifadə etdiyi qurğunun təhlükəsizliyinə yönəlmiş müxtəlif təhlükələr baş verir. Bu təhlükələri bir neçə risk qrupuna bölmək olar. Risk təhdidlərin sistemə (obyekt, resurs və ya proses) təsirinin nə dərəcədə təhlükəli olduğunu müəyyən edir [4]:

- Məzmunla bağlı risklər;

- İnformasiya təhlükəsizliyi ilə bağlı risklər;

- Ünsiyyət və davranışla bağlı risklər;

Mozmunla bağll risklor. İnternetdə paylaşılan və uşaqlar üçün qeyri-qanuni, qeyri-münasib hesab edilən məlumatların istifadəsi ilə əlaqədardır. Belə kontentləri uyğunsuz və qanunsuz məzmun olaraq iki hissəyə bölmək olar. Uyğunsuz məzmuna ölkənin mədəniyyətinə, mentalitetinə zidd olan və qanunvericiliyə əsasən təsdiq olunmuş qaydada uşaqların yaş qrupuna uyğun olmayan materiallar aid edilir. Buraya şiddət, qərəzli məzmun, erotizm və pornoqrafiya, normadan kənar leksika (söyüş, jarqon) ilə danışıq və irqi ayrı seçkiliyi təbliğ edən materiallar aid edilir. Suisid (intihara cəlb) istiqamətli materiallar, sektant materiallar, partlayic1 maddələrin, narkotik vasitələrin hazırlanması və istifadəsi ilə bağlı məzmun daxildir [4].

Hər bir ölkənin qanunvericiliyinə əsasən, müxtəlif materiallar qanunsuz məzmun hesab olunur. Bir çox ölkələrdə uşaq və yeniyetmələrlə cinsi əlaqəli materiallar, 


\section{“Informasiya tohlükosizliyinin aktual multidissiplinar elmi-praktiki problemlori” \\ IV respublika konfransl, 14 dekabr 2018-ci il}

pornoqrafik məzmun, cinsi zorakılı̆̆ı təbliğ edən məzmun, ekstremizm və irqçiliyə, nifrətə qarşı həssaslıq da daxil olmaqla zorakılıq təsvirlərini ehtiva edən materialların yayımlanması qadağan edilir və qanunsuz hesab olunur.

Informasiya tahlükosizliyi ilo bağll risklar. Vebsəhifələri açarkən reklam və pulsuz proqram təminatları avtomatik olaraq kompüterin yaddaşına yüklənir. Fərdi məlumatların açıqlanması, virus hücumuna məruz qalma, onlayn firıldaqçlıq və spam informasiya təhlükəsizliyi ilə bağlı riklərə aiddır $[1,4]$.

Zarərli Proqramlara kompüterdə işləyərkən həm istifadəçinin özünə, həm də istifadə etdiyi kompüterə mənfi təsir göstərən proqramlar (viruslar, casus proqramları, istənilməyən reklam proqramları, zərərli kodun müxtəlif formalar1) daxildir[1,4].

Spam reklam materialları yerləşdirilmiş və arzuolunmayan, istənilməyən e-poçtlardır. Belə məktublar istifadəçinin vaxtını və ona sərf edilən İnternet trafikini istismar edir[1,4].

Kiberdəladuzluq istifadəçilərin aldadılması məqsədini daşıyan (gizli məlumatların oğurlanması, köhnə məlumatlardan istifadə, Nigeriya məktubları, fişinq, istək və farming və s. ) kibercinayətkarlığın bir növüdür.

Fişinq (ing. "Phishing”) texnologiyası kiberdələduzluğun ən çox yayılmış formasıdır. Hakerlər qanunsuz maddi mənfəət əldə etmək üçün bundan istifadə edir. Mahiyyəti ondan ibarətdir ki, saxta elektron poçta hansısa populyar İnternet qovşağa aparan hiperkeçid daxil edilir, əslində isə bu istifadəçini görünüşcə rəsmi sayta bənzəyən başqa bir qovşağa aparır. İstifadəçini rəsmi saytda olduğuna inandırdıqdan və onların etimadını qazandıqdan sonra onun parolunu, kredit kartının nömrəsini və digər məxfi məlumatlarını daxil etməyə yönəltməyə cəhd göstərirlər. Sonradan bu informasiyadan istifadəçiyə zərər vurmaq üçün istifado edilir [5].

Ünsiyyat vo davranışla bağlı risklor. Bu qrupa daxil olan təhlükələr İnternet istifadəçilərinin insanlarla qarşılıqlı əlaqələrinə aiddir. İnternetdə uşaqlar çox vaxt kiberhücuma məruz qalaraq kibercinayətkarların (pedofillər və s.) qurbanına çevrilir. Bu əlaqəyə azyaşlılar və böyük yaşlı insanlar arasında olan münasibətlər aid edilir.

Kiberzorakılıq (kiberöküzlük, ing. Cyberbullying) virtual terrordur (bull ingiliscə öküz mənasını verir), tərcümədə bu söz: təcavüzkar hücum, təcavüz, təhqir, təhrik etmək və qəzəbləndirmək kimi mənaları ifadə edir. Elektron poçt, ani mesajlaşma, çat otaqları, sosial şəbəkələr, websaytlar, eləcə də mobil telefonlar vasitəsilə həyata keçirilir [6]. İnsanlara psixoloji zərər vurmaq üçün virtual hücumdur və dörd əsas komponentdən ibarətdir:

- Təcavüzkar və mənfi davranışdır;

- Müntəzəm olaraq həyata keçirilir;
- İştirakçılar arasında müxtəlif gücə (qeyri-bərabər güc) malik münasibətlər baş verir;

- Qəsdən olunan bir davranışdır.

Təzahür formasından asılı olmayaraq kiberzorakılıq qurbana ciddi zərər verə və ən kəskin hallarda faciəli nəticələrə belə gətirib çıxara bilər. Bu davranışlara ciddiyə alınmayan zarafatlar, psixoloji virtual terror, insanın ölümünə səbəb olan davranış (bulisid - zorakılığa görə qurbanın ölümü) aiddir. Belə insanlar həm mesajla öz qurbanını təhqir edir, həm də qurbanın veb-səhifəsini ləğv edir, alçaldıcı məzmunun yerləşdiyi yerlərdə saxta səhifələr yaradır və həmin insanın ünvanına təhqiramiz və əxlaqsız mesajlar yayirlar.

İnternet vasitəsilə fotoşəkillər göndərməklə insanları təqib, təhqir, təcavüz, cinsi təcavüz etmək kimi davranışlar bu fikirlərə aiddir. İnsanlarda qüsur tapmaq, yersiz irad tutmaq, təhrik etmək, əsəbləşdirmək, bəhanə axtarmaq, təngə gətirmək, narahat etmək, şaiyələr yaymaq, ələ salmaq, sataşmaq və aqressiv vəziyətə gətirmək kimi xüsusiyyətləri də aid etmok olar.

Kiberzorakılıq tamamilə tanımadığınız insanlar, dostunuz, dostunuzun dostu olan insan tərəfindən həyata keçirilə bilər. Hətta bu qrup şəklində olan insanlar da ola bilər ki, onlar bir-birilərini tanıyırlar. Bəzən yeni yaradılmış bir qrup köhnə qrupun təzyiqlərinə də məruz qala bilər.

Internet-asılılıq. $\mathrm{Bu}$ problem İnternetin inkişafından sonra yaranmışdır. Bəzi insanlar virtual aləmə o qədər aludə olurlar ki, onlar günün çox hissəsini - təxminən 18 saata qədərini kompüter arxasında keçirirlər. Uşaqların və yeniyetmələrin hər şeyi öyrənmək istəyi onların İnternetdə saatlarla vaxt keçirməsinə səbəb olur və getdikcə ondan asılı vəziyyətə düşür. Belə uşaqlar dərslərini yaxşı hazırlaşa bilmir, yeməyini vaxtl1-vaxtında yemir, real ünsiyyətdən daha çox virtual ünsiyyətə üstünlük verir, sosiallaşa bilmir, bir sözlə cəmiyyətdən qaçır. Onların sağlamlığı ilə bağlı problemlər yaranır (gözləri zəifləyir, fiziki görkəmi dəyişi, pinqivinləşir və s. ). İnternetdən asılılığın ən təhlükəli cəhətlərindən biri belə uşaqların cinayətkarların hədəfinə çevrilməsidir [7, 8].

Azartlı oyunlar. Uşaqların İnternetdə saatlarla vaxt keçirməsinə səbəb olan məqamlardan biridir. Adi oyun saytlarında insanların oyun pulları ilə oynayaraq udmasına və uduzmasına yol verilir. Pullu oyunlar olan saytlarda isə həqiqi pullar vasitəsilə oynanılan oyunlar yerləşdirilir.

Şəbəkədə oynalınan ideologiya xarakterli oyunlar şiddəti, zorakılığı, dini ayrıseçkiliyi təbliğ edir. Oyunlarda müxtəlif ideyalar təbliğ olunur. Uşaqlara İnternetin “diktə” etdiyi mədəniyyətləri təbliğ edir, gənc nəsli milli adət-ənənələrdən uzaqlaşdırır $[1,8]$.

\section{III. İNTERNET MÜHITTINDə UŞAQLARIN QORUNMASINI TOMIN EDӘN HÜQUQI SONӘDLӘR}

İnternetin həyatımıza daha da dərindən nüfuz etməsi, səlahiyyətli insanların diqqətini özünə çəkir. Deməli, virtual mühiti tənzimləyəcək yeni qanunların yaradılmasına ehtiyac 


\section{"Informasiya tohlükssizliyinin aktual multidissiplinar elmi-praktiki problemlori” \\ IV respublika konfransl, 14 dekabr 2018-ci il}

artır. Qeyd olunan tədbirlərlə yanaşı, uşaq psixologiyasına, sağlamlığına təsir edən ziyanlı kontentin qarşısının alınmasında qanunla tənzimlənməni tələb edir. Uşaqları mövcud təhlükələrdən qoruma probleminin hüquqi səviyyədə tənzimlənməsi üçün əksər dünya ölkələrində müəyyən normativ sənədlər tətbiq edilir. Uşaqlara qarşı olan zorakılıqların, aqressiyanın, kibercinayətlərin və s. qarşısının alınması və uşaq təhlükəsizliyinin təmin olunmasına dair ölkələrin qanunvericiliyində müxtəlif yanaşmalar tətbiq edilir. Aşağıda onlardan bəziləri haqqında məlumat verilir.

Avropa Şurasının "Uşaqların zərərli kontentdən qorunması" hesabatında uşaqlar üçün nəzərdə tutulmuş ziyanlı informasiyanın növləri aşağıdakı kimi təsnifatlaşdırılır [9]:

Tabliğat xarakterli informasiya:

- Sağlamlığa zərərli informasiya və intihara cəlb etmo;

- Spirtli içkilərə, tütün, narkotik və s. sövq etmə;

- Azartlı oyunlar;

- Cinsi istismar;

- Dilənçilik;

- İnsanlara və heyvanlara qarşı qəddarlıq;

- Ailələyə hörmətsizlik və qeyri ənənəvi cinsi münasibətlərə sövq etmə;

- Qanun pozuntusuna və ya cinayətkarlığa sövq etmə;

- Pornoqrafik informasiya.

2. Senzuradan kanar ifadalar:

- Söyüş;

- Jarqon;

- Təhqiramiz ifadələr.

3. Pornoqrafik informasiya:

- Foto və təsvirlər şəklində cinsi münasibət.

4. Şiddat va qorxunu tabliğ edan mazmun:

- Şiddət;

- Qəddarliq;

- Zorakiliq;

- Bədbəxt və qəzalı hadisələrin şəkillərinin verilməsi.

5. Uşaq haqqında fordi molumat:

- Uşağın kimliyi;

- Yaşadığ1 məkan, oxuduğu məktəb haqqında və s.

Amerika Birləşmiş Ştatlarında 2000-ci ilin oktyabrında ABŞ Konqresi tərəfindən uşaqları İnternetdə yerləşdirilən cinsi istismar və digər arzuolunmaz materiallardan qoruyan "Uşaqların İnternetdə Mübarizə Qanunu" qəbul edilimişdir [10]. Həmçinin "İnternetdə uşaqların məxfiliyinin qorunması haqqında" qanun qəbul edilmişdir. Qanun Birləşmiş Ştatların qanunvericiliyinə əsasən 13 yaşına çatmamış şəxslərin və ya təşkilatlarda olan şəxsi məlumatların toplanmasına aiddir [11].

27 iyul 2006-cı ildə ABŞ-da Adam Valş uşaq mühafizəsi və təhlükəsizliyi aktı (Adam Walsh Child Protection and Safety Act) qəbul olunmuşdur. Məqsəd uşaqları istismar və zorak1 cinayətlərdən qorumaq, uşaq pornoqrafiyasının qarşısının alınmasını bütün səviyyələrdə həyata keçirərək cinsi istismarçıların uşaqlara əlyetənliyinin qarşısını almaqla uşaqların internetdə təhlükəsizliyini təmin etməkdir. Qanunvericiliyə əsasən son 5 ildə bu tip cinayətlərdə iştirak etmiş şəxslərin barmaq izləri Milli Cinayətlərin məlumat bazasına daxil edilir [12].

2016-cı ilin mayında Belarus Respublikasının "Uşaq hüquqları haqqında" Qanununda müvafiq dəyişikliklər edilmişdir və 1 iyul 2017-ci il tarixindən qüvvəyə minmişdir [13].

2 iyul 2018-ci il tarixdə "Uşaqların sağlamlığına və inkişafina zərər verən məlumatlardan qorunması haqqında" Qazaxıstan Respublikasının Qanunu qəbul edilmişdir [14].

"Uşaqların sağlamlığına və inkişafina zərər verən məlumatlardan qorunması haqqinda" Federal Qanunu 01 sentyabr 2012-ci il tarixdə qüvvəyə minmişdir. Rusiya qanunvericiliyinə görə, uşaqların informasiya təhlükəsizliyi İnternetdə yayılmış məlumatların onların sağlamlığına, fiziki, zehni inkişafina təsir edən və mənəvi cəhətdən zərər verən informasiyalar ilə əlaqəli risklərdən onların qorunmasıdır [15].

\section{AZӘRBACANDA UŞAQLARIN INFORMASIYA TӘHLÜKӘSIZLIYININ HÜQUQ MÜSTӘVISIINDӘ TOMINI}

Ölkəmizdə informasiya təhlükəsizliyinin təmin edilməsinin qanunvericilik bazasının formalaşdırılması və inkişaf etdirilməsi istiqamətində bir sıra mühüm konseptual sənədlər, normativ-hüquqi aktlar qəbul edilmişdir.

Azərbaycan Respublikası Prezidentinin 2014-cü il 02 aprel tarixli sərəncamı ilə təsdiq edilmiş "Azərbaycan Respublikasında İC-nin inkişafına dair 2014-2020-ci illər üçün Milli Strategiya" -da "Uşaqların qanunazidd və təhlükəli kontentdən qorunması üçün "təhlükəsiz İnternet" mexanizminin işlənilməsi və tətbiqi" üçün müəyyən tədbirlərin görülməsi nəzərdə tutulur [16].

Azərbaycan Respublikasının Prezidentinin 29 aprel 2016c1 il tarixli "Telekommunikasiya haqqinda" Azərbaycan Respublikasının Qanununda dəyişikliklər edilməsi barədə Azərbaycan Respublikasının Qanununda (34.1.2-1. Uşaqların sağlamlığına və inkişafina ziyan vuran informasiyadan qorunması üçün tədbirlər görülməsini tələb etmək) bu haqda qeyd olunmuşdur [17].

Qanunda uşaqların sağlamlığı və inkişafi üçün zərərli məlumatlar və onlardan qorunma təqdim olunur. Ümumiyyətlə, ölkəmizdə uşaqların arzuolunmayan 


\section{“Informasiya tohlükosizliyinin aktual multidissiplinar elmi-praktiki problemlori” IV respublika konfransl, 14 dekabr 2018-ci il}

məlumatlardan qorunması və İnternet təhdidlərinin qarşısının alınması məqsədilə təklif olunan tənzimləyici çərçivənin olduqca əhəmiyyətli olduğunu qeyd etmək lazımdır. "Uşaqların zərərli informasiyadan qorunması haqqında" Azərbaycan Respublikasının 2018-ci il 30 oktyabr tarixli qanunun 3-cü maddəsində "Uşaqların zərərli informasiyadan qorunması sahəsində əsas prinsiplər" verilmişdir və orada göstərilir ki, "zorakılığın, qəddarlığın, narkotik vasitələrin və psixotrop maddələrin, alkoqollu içkilərin və tütün məmulatlarının, cəmiyyət əleyhinə davranışın, pornoqrafik xarakterli informasiyanın təbliğinin yolverilməzliyi" əsas faktordur. Qanun uşaqların fiziki, zehni və mənəvi inkişafina zərər verən məlumatlardan qorunması üçün qanuni mexanizmləri müəyyən edir [18].

Qanunda uşaqların yaş həddinə görə kateqoriyalara ayrılması onu göstərir ki, uşaqlar üçün nəzərdə tutulmuş informasiya məhsulları hər bir yaşa uyğun olaraq analiz olunmalı və təsnifatlandırılmalıdır. Yaş həddi $(0+, 6+, 12+$, $16+, 18+)$ nəzərə alınmaqla uşaqlar arasında dövriyyəsi qadağan edilən informasiyanın növlərinə aşağıda qeyd olunan problemlər aid edilir [18]:

- Zorakılığı və qəddarlığı təbliğ edən informasiya;

- Cinayətkarlığı təbliğ edən informasiya;

- Uşaqların həyat və təhlükəsizliyinə potensial təhlükə yaradan əməlləri təbliğ edən informasiya;

- Oxlaqdan kənar leksik (söyüş) məzmunlu informasiya;

- Erotik və pornoqrafik xarakterli informasiya;

- Qeyri-məişət leksik (jarqon) məzmunlu informasiya;

- Qorxu məzmunlu informasiya.

Görülən tədbirlərə baxmayaraq, müasir dövrdə uşaqlar üçün təhlükəli məlumatların yayılması ilə bağlı yeni risklərin artması davam etməkdədir. Yeni qəbul edilmiş və uşaqların qorunması məqsədini daşıyan qanun və sərəncamlar uşaqların sağlam böyüməsi, tərbiyəsi, sosiallaşmasına kömək edir. Onlarda yüksək səviyyədə vətəndaşlıq, vətənpərvərlik hisslərinin yaranmasında böyük rol oynayır və yeni sosial dövlət sisteminin formalaşmasına çağırır.

\section{NəTICə}

Maarifləndirici, təşkilati və proqram texniki tədbirlərin həyata keçirilməsi uşaq təhlükəsizliyinin təmin olunması probleminin həllində əhəmiyyətlidir və işə öz müsbət təsirini göstərir.

Araşdırmalardan məlum olur ki, bütün dövlətlərdə olduğu kimi, Azərbaycanda uşaqların informasiya təhlükəsizliyi ilə bağlı problemlər aktualdır. Hər il yeni-yeni qanun və sərəncamların verilməsinə baxmayaraq, zərərli məlumatlar İnternet qlobal şəbəkəsi vasitəsilə (elektron oyunlar, qorxu və terrorizmi təbliğ edən cizgi filmləri, videoçarxlar və s.) uşaqlara ötürülür.

Müasir həyatın mürəkkəbliyi, İnternet təhdidlərin çoxluğu, kibercinayətlərin sayının artması və eyni zamanda uşaqların təcrübəsizliyi göstərir ki, onları istər real həyatda, istərsə də virtual aləmdə arzu olunmayan məlumatlardan qoruması problemi kompleks yanaşma tələb edir. Dövlət və ictimai təşkilatlar bu problemin ətrafında birləşməlidir. Әn başlıcası isə valideyn, himayədar və s. cavabdeh şəxlərin təhlükələr barədə məlumatlı olması və yüksək informasiya mədəniyyətinin olması vacibdir.

\section{ӘDӘВIYYAT}

[1] S.S.Ocaqverdiyeva. İnternet mühitinde uşaqların təhlükəsizliyinin təmin edilməsi məsələləri / İnformasiya Cəmiyyəti Problemləri, 2018, N: 1. s. 99-107.

[2] H.Ros, D. George. Young children's concepts of danger/ British Journal of Developmental Psychology , 2000,vol.18, pp.103-119.

[3] N.T Abdelmajeed. Parental Role in Protecting Children and Dangers of Social Networks Sites/ Journal of information security and cybercrimes research (JISCR). Vol 1, No 1 (2018), pp. 19-27.

[4] C. А.Котова. Дети в интернете: контентные и коммуникационные риски//Поведение риска: современные направления исследования и профилактики Материалы Международной научнопрактической конференции 24 февраля 2012 года, стр. 232-245.

[5] J. Hong. "The state of phishing attacks"/ Communications of the ACM, vol. 55, №1, pp. 74-81, 2012.

[6] J.Cenat, M.Blais, F.Lavoie, P.Caron, M.Hebert. Cyberbullying victimization and substance use among Quebec high schools students: The mediating role of psychological distress/ Computers in human behavior, vol.89. pp. 207-212, 2018.

[7] R.M. Oliquliyev, R.Ş. Mahmudov. İnformasiya asılılı̆̆ı problemləri və onlarla mübarizə yolları/ İnformasiya Texnologiyaları nəşriyyatı, Bakı, 2009, $62 \mathrm{~s}$.

[8] Д.А. Богданова, А.А. Федосеев Внимание - Интернет.//Открытое образование. №2, стр. 89-99, 2010.

[9] Доклад для Совета Европы «Защита детей от вредного контента», https://www.coe.int/en/web/freedom-expressi

[10] Children's Internet Protection Act (CIPA), https://www.fcc.gov/consumers/guides/childrens-internet-protectionact

[11] COPPA - Children's Online Privacy Protection Act, http://www.coppa.org/coppa.htm

[12] Adam Walsh Child Protection and Safety Act, http://www.ncsl.org/research/civil-and-criminal-justice/adam-walshchild-protection-and-safety-act.aspx

[13] Закон Республики Беларусь 19 ноября 1993 г. N 2570-XII, О правах ребенка, http://pravo.by/document/?guid=3961\&p0=V19302570

[14] Закон Республики Казахстан от 2 июля 2018 года № 169-VI «O защите детей от информации, причиняющей вред их здоровью и развитию» (не введен д в https://online.zakon.kz/document/?doc_id=39797352\#pos=201;-45

[15] Защита детей от информации, которая может причинить вред их здоровью и развитию, http://pravo.by/novosti/obshchestvennopoliticheskie-i-v-oblasti-prava/2017/june/24766/

[16] Azərbaycan Respublikasında informasiya cəmiyyətinin inkişafina dair 2014-2020-ci illər üçün Milli Strategiya, 02 aprel 2014-cü il// www.president.az

[17] "Telekommunikasiya haqqında" Azərbaycan Respublikasının Qanununda dəyişikliklər edilməsi barədə, Bakı şəhəri, 29 aprel 2016-c1 il, № 212-VQD, http://www.e-qanun.az/framework/32956 
[18] "Uşaqların zərərli informasiyadan qorunması haqqında" Azərbaycan Respublikasının 2018-ci il 30 oktyabr tarixli 1310-VQ nömrəli Qanun https://president.az/articles/30815

\title{
CHILDREN'S INTERNET SAFETY LEGISLATION BASE IN THE E-STATE ENVIRONMENT
}

Sabira Ojagverdieva

Institute of Information Technologies of ANAS,

Baku, Azerbaijan

allahverdiyevasabira@gmail.com

\begin{abstract}
The threats faced by children in the Internet are classified by analysing in the article. The information on normative documents adopted on the basis of legislation at the state level in Azerbaijan and different countries of the world due to the safety of children on the Internet environment.
\end{abstract}

Keywords - children safety, damaging content, harmful information, Internet threats, addiction. 